\title{
PENINGKATAN DAYA TETAS TELUR DAN SINTASAN LARVA IKAN NILA (Oreochromis niloticus) DENGAN PENGGUNAAN OBAT-OBATAN
}

\author{
Hambali Supriyadi", Oman Komarudin"), Pipik Taufik ${ }^{*}$, \\ Zulkifli Jangkaru*) dan Sidi Asih")
}

\begin{abstract}
ABSTRAK
Penelitian bertujuan untuk mengetahui cara penanganan telur, larva dan induk bagi pening. katan produksi benih nila melalui penerapan manajemen kesehatan ikan. Dalam penelitian ini digunakan beberapa macam anti jamur untuk penanganan telur serta beberapa macam antibiotik dan vaksin dengan berbagai dosis untuk peningkatan daya sintasan larva.

Hasil penelitan menunjukkan bahwa anti jamur phenol $(1 \mathrm{mg} / \mathrm{L})$ dan iodin $(5 \mathrm{mg} / \mathrm{L}) \mathrm{meng}$. hasilkan daya tetas telur tertinggi yaitu berturut-turut $86,6 \%$ dan $92,6 \%$. Pengaruh penggunaan antibiotik terhadap daya tetas telur menunjukkan bahwa oxytetracyclin $5 \mathrm{mg} / \mathrm{L}$ menghasilkan laju sintasan larva tertinggi yaitu $64,6 \%$, sedangkan penggunaan vaksin pada larva yang dilakukan di kolam menghasilkan laju sintasan larva relatif lebih rendah $(72,33 \%)$ apabila dibandingkan dengan kontrol $(74,33 \%)$.
\end{abstract}

ABSTRACT: The application of chemotherapeutant for increasing hatching and survival rates of nile tilapia larvae. By: Hambali Supriyadi, Oman Komarudin, Pipik Taufik, Zulkifli Jangkaru and Sidi Asih.

The study is aimed to know the procedures of eggs and larval handling of nile tilapia (Oreohromis niloticus) through application of chemotherapeutant. The fungicides of phenol, iodin and malachite green oxalate with the different dose levels were applied to know the best result on the hatching rate. Some antibiotics and vaccines were also used for increasing the larval survival.

The result showed that phenol $1 \mathrm{mg} / \mathrm{L}$ and iodin $5 \mathrm{mg} / \mathrm{L}$ were effective for eggs treatment, indicated by the high hatching rate i.e. $86.6 \%$ and $92.6 \%$ respectively. Treatment of larva by using antibiotic oxytetracycline $5 \mathrm{mg} / \mathrm{L}$ was effective for control of bacterial disease infection in larvae, indicated by high survival rate $(64.6 \%)$. Meanwhile treatment of larvae by using aeromonas vaccine, did not indicate high level of survival (72.33\%) compared to control $(74.33 \%)$

KEYWORDS: chemotherapeutant, hatching rate, survival rate, phenol, iodin, malachite green, oxytetracyclin, vaccine.

\section{PENDAHULUAN}

Ikan nila (Oreochromis niloticus) merupakan salah satu komoditas ikan air tawar yang memperoleh perhatian cukup besar bagi usaha perikanan. Komoditas tersebut juga merupakan jenis ikan budidaya yang penting di negara-negara tertentu seperti Israel dan Taiwan (Wohlfarth \& Hulata, 1983).

Masalah yang dihadapi sekarang ialah tidak terpenuhinya kebutuhan benih. Kurangnya per- sediaan benih ini antara lain diakibatkan oleh rendahnya produksi larva yang merupakan akibat dari rendahnya daya tetas telur, karena infeksi oleh bakteri maupun jamur (Sachlan, 1975). Hal tersebut berlaku terutama pada sistem penetasan secara intensif.

Penelitian yang dilakukan pada tahun 1991/ 1992 membuktikan bahwa ikan nila merah dapat terinfeksi oleh bakteri Aeromonas hidrophyla dan Enterobacter spp. (Supriyadi, 1992). Demikian pula penggunaan beberapa antibiotik dalam

Peneliti pada Balai Penelitian Perikanan Air Tawar 
pengobatan terhadap infeksi bakteri Enterobacter spp. dan Aeromonas hidrophyla telah diteliti (Supriyadi, 1992).

Untuk penyediaan benih yang cukup secara berkesinambungan, berkualitas tinggi dan tahan terhadap penyakit, salah satu caranya melalui aplikasi manajemen kesehatan ikan (Plumb, 1992), termasuk di dalamnya adalah perawatan telur dan larva sebaik-baiknya serta pembentukan kekebalan sedini mungkin.

Dalam tulisan ini dikemukakan hasil penelitian cara perlakuan telur dan larva serta usaha untuk menimbulkan kekebalan dengan meng. gunakan vaksin.

\section{BAHAN DAN METODE}

\section{Perlakuan Telur dengan Anti Jamur}

Telur ikan nila dikoleksi dari induk dengan bobot $119 \mathrm{~g}$ dan $227 \mathrm{~g}$. Telur ikan dibagi menjadi 30 kelompok masing-masing terdiri atas 50 butir. Anti jamur yang dipakai adalah: phenol (dosis 0; 0,$5 ; 1,0 ; 2.0 \mathrm{mg} / \mathrm{L}$ ); iodin (dosis $0 ; 2,5 ; 5,0$ dan 7,5 $\mathrm{mg} / \mathrm{L}$ ) dan malachite green (dosis $0 ; 0,1 ; 0,2$ dan $0,4 \mathrm{mg} / \mathrm{L})$. Telur ditempatkan dalam akuarium ukuran $25 \times 25 \times 20 \mathrm{~cm}$ dengan volume air dua liter, serta diaerasi. Perendaman telur dengan anti jamur dilakukan selama 12 jam, dan setelah itu air yang mengandung obat diganti dengan air bersih. Jumlah larva yang hidup kemudian dihitung pada tujuh hari dari mulai pergantian air. Tiap perlakuan dilakukan dengan tiga kali ulangan, kecuali untuk kontrol hanya digunakan tiga wadah untuk keseluruhan. Data dianalisis secara deskriptif.

\section{Perlakuan Larva dengan Antibiotik}

\section{a. Penelitian di laboratorium}

Larva ikan nila yang dipakai berumur dua hari setelah menetas dengan ukuran panjang 0,45-0,5 cm. Larva dibagi menjadi 30 kelompok, masing-masing terdiri atas 50 ekor. Antibiotik yang dipakai sebagai perlakuan adalah: enrofloxalin, oxytetracyclin dan erythromycin dengan dosis untuk masing-masing antibiotik sebesar 0 , 5,10 dan $15 \mathrm{mg} / \mathrm{L}$. Larva direndam dalam larutan obat selama 24 jam pada akuarium berukuran 25 x $25 \times 20 \mathrm{~cm}$ dengan volume air dua liter dan setelah itu airnya diganti dengan air bersih, dan diaerasi. Tiap perlakuan dilakukan dengan tiga kali ulangan, kecuali untuk kontrol hanya digunakan tiga wadah. Pengamatan dilakukan terhadap sintasan larva sampai dua minggu setelah perlakuan.

\section{b. Penelitian di kolam}

Larva ikan nila yang dipakai berumur dua hari setelah menetas. Larva dibagi menjadi 15 kelompok, masing-masing terdiri atas 100 ekor.

Larva kemudian diperlakukan dengan antibiotika erythromicyn, enrofloxacin dan oxytetracyclin dengan dosis masing-masing $5 \mathrm{mg} / \mathrm{L}$. Selain itu digunakan juga vaksin aeromonas dengan dosis $10^{7} \mathrm{sel} / \mathrm{mL}$ dan kontrol. Larva direndam dalam antibiotik dan vaksin tersebut selama 30 menit. Perendaman dilakukan di dalam akuarium $60 \times 30 \times 30 \mathrm{~cm}$ dengan volume air 40 liter. Larva kemudian dipindahkan ke dalam hapa dengan ukuran 0,5 x $1 \times 0,6 \mathrm{~m}$ dengan ketinggian air $40 \mathrm{~cm}$. Selama pemeliharaan, larva diberi pakan berupa tepung yang diberikan secukupnya. Tiap perlakuan diulang tiga kali. Pengamatan dilakukan terhadap sintasan ikan sampai dengan satu bulan. Data dianalisis secara deskriptif.

\section{HASIL DAN PEMBAHASAN}

\section{Perlakuan Telur}

Hasil penelitian pengaruh bahan anti jamur terhadap daya tetas telur dapat dilihat pada Tabel 1.

Pada penggunaan beberapa bahan anti jamur ternyata bahwa phenol dan iodin cukup baik bagi daya tetas telur dibanding dengan malachite green oxalat. Padahal malachite green $0,2 \mathrm{mg} / \mathrm{L}$, selama ini telah banyak disarankan pemakaiannya dalam pengobatan penyakit akibat jamur (Anderson, 1992). Daya tetas telur tertinggi terdapat pada perlakuan iodin dosis $5 \mathrm{mg} / \mathrm{L}(92,67 \%)$ dan phenol $1 \mathrm{mg} / \mathrm{L}(86,67 \%)$. Perlakuan iodin 2,5 $\mathrm{mg} / \mathrm{L}$ mampu meningkatkan daya tetas telur sebesar 90,67\%. Hal ini dapat dipakai untuk pertimbangan efisiensi pemakaian obat karena daya tetas telur yang dihasilkan antara dosis anti jamur $2,5 \mathrm{mg} / \mathrm{L}$ dan $5 \mathrm{mg} / \mathrm{L}$ hampir sama. Artinya dengan pemakaian dosis $2,5 \mathrm{mg} / \mathrm{L}$ saja sudah dapat menghasilkan daya tetas telur yang tinggi. 


\section{Perlakuan Larva}

Hasil penelitian pengaruh antibiotik ter-hadap sintasan larva di laboratorium dapat dilihat pada Tabel 2. Sedangkan hasil penelitian di kolam dapat dilihat pada Tabel 3.
Hasil uji pengaruh dari tiga jenis antibiotik terhadap sintasan larva ikan nila dalam akua. rium menunjukkan bahwa hanya oxytetracyclin yang memberikan pengaruh positif yaitu menghasilkan laju sintasan larva yang tinggi. Laju sintasan larva dari perlakuan oxytetracyclin ber-

Tabel 1. Pengaruh berbagai dosis anti jamur phenol, iodine dan malachite green oxalate terhadap daya tetas telur (\%) Oreochromis niloticus.

Table 1. The effect of different doses of phenol, iodine and malachite green oxalate on the hatching rate (\%) of Oreochromis niloticus eggs.

\begin{tabular}{lcc}
\hline $\begin{array}{c}\text { Anti jamur } \\
\text { Anti mycotics }\end{array}$ & $\begin{array}{c}\text { Dosis (Dosage) } \\
(\mathbf{m g} / \mathrm{L})\end{array}$ & $\begin{array}{c}\text { Daya tetas (Hatching rate) } \\
(\%) *\end{array}$ \\
\hline \multirow{2}{*}{ Phenol } & 0.00 & $48.67 \pm 0.94$ \\
& 0.50 & $52.67 \pm 7.73$ \\
& 1.00 & $86.67 \pm 5.73$ \\
& 2.00 & $68.00 \pm 14.70$ \\
Iodin & 0.00 & $48.67 \pm 0.94$ \\
& 2.50 & $90.67 \pm 4.71$ \\
& 5.00 & $92.67 \pm 6.60$ \\
Malachite & 7.50 & $89.33 \pm 5.25$ \\
green & 0.00 & $48.67 \pm 0.94$ \\
& 0.10 & $33.33 \pm 9.97$ \\
& 0.20 & $60.67 \pm 13.88$ \\
& 0.40 & $50.00 \pm 16.57$ \\
\hline *) Rata-rata dari tiga
\end{tabular}

Tabel 2. Pengaruh beberapa antibiotik terhadap sintasan (\%) larva tilapia dalam akuarium pada dua minggu setelah perlakuan.

Table 2. The effect of some antibiotics on the survival rate (\%) of tilapia larvae in the aquarium, after 2-week treatment.

\begin{tabular}{ccc}
\hline $\begin{array}{c}\text { Antibiotik } \\
\text { Antibicotics }\end{array}$ & $\begin{array}{c}\text { Dosis (Dosage) } \\
(\mathbf{m g} / \mathrm{L})\end{array}$ & $\begin{array}{c}\text { Sintasan (Survival rate) } \\
(\%)\end{array}$ \\
\hline Enrofloxacin & 0.00 & $36.00 \pm 5.88$ \\
& 5.00 & $50.00 \pm 2.83$ \\
& 10.00 & $38.00 \pm 6.53$ \\
Oxytetracyclin & 15.00 & $30.00 \pm 11.43$ \\
& 0.00 & $36.00 \pm 5.88$ \\
& 5.00 & $64.67 \pm 3.40$ \\
Erythromycin & 10.00 & $60.00 \pm 4.32$ \\
& 15.00 & $52.67 \pm 6.18$ \\
& 0.00 & $36.00 \pm 5.88$ \\
& 5.00 & $34.67 \pm 8.99$ \\
& 10.00 & $18.67 \pm 6.60$ \\
& 15.00 & $28.67 \pm 9.97$ \\
\hline *) Rata-rata dari tiga ulangan (average of 3 replicates) &
\end{tabular}


Tabel 3. Pengaruh beberapa antibiotik (enrofloxaxin, oxytetracyclin, erythromycin) dan vaksin terhadap sintasan (\%) larva tilapia di kolam pada umur satu bulan setelah perlakuan.

Table 3. The effect of some antibiotics (enrofloxacin, oxytetracyclin, erythromycin) and vaccine on the survival rate (\%) of tilapia larvae in the pond after one month treatment.

\begin{tabular}{lcc}
\hline $\begin{array}{c}\text { Antibiotik dan vaksin } \\
\text { Antibiotics and vaccine }\end{array}$ & $\begin{array}{c}\text { Dosis } \\
\text { Dosage }\end{array}$ & $\begin{array}{c}\text { Sintasan (Survival rate) } \\
\text { (\%) * }\end{array}$ \\
\hline Enrofloxacin & $5 \mathrm{mg} / \mathrm{L}$ & $94.33 \pm 4.64$ \\
Oxytetracycline & $5 \mathrm{mg} / \mathrm{L}$ & $86.67 \pm 7.58$ \\
Erythromycin & $5 \mathrm{mg} / \mathrm{L}$ & $98.33 \pm 1.70$ \\
Vaksin (Vaccine) & $10^{7} \mathrm{sel} / \mathrm{mL}$ & $72.33 \pm 3.09$ \\
Kontrol (Control) & - & $74.33 \pm 2.05$ \\
\hline
\end{tabular}

*) Rata-rata dari tiga ulangan (average of 3 replicates)

kisar antara $52,67 \%$ hingga $64,67 \%$. Sintasan tertinggi dihasilkan dari perlakuan dosis $5 \mathrm{mg} / \mathrm{L}$ $(64,67 \%)$. Oxytetracyclin pada dosis yang sama juga sering digunakan dalam pengobatan penyakit infeksi bakteri pada udang (Baticados \& Paclibare, 1992).

Enrofloxacin telah banyak diteliti efektivitasnya bagi pengobatan penyakit bakterial seperti yang telah dilakukan oleh Supriyadi (1992) yang menyatakan bahwa penggunaan enrofloxacin 10 $\mathrm{mg} / \mathrm{L}$ dengan cara perendaman selama 12 jam pada ikan nila merah (bobot rata-rata 7,6 g) menghasilkan sintasan larva rata-rata $95,5 \%$. Tujuan penggunaan antibiotik pada penelitian tersebut adalah untuk mengurangi infeksi bakteri pada ikan setelah penanganan. Sedangkan aplikasinya pada larva ikan nila dimaksudkan juga untuk mencegah infeksi bakteri pada larva tersebut mengingat keadaan larva masih lemah dan sensitif terhadap infeksi penyakit terutama penyakit bakteri.

Uji efektivitas antibiotik pada larva yang ditempatkan di kolam menunjukkan bahwa penggunaan ketiga antibiotik menghasilkan daya sintasan yang tinggi yaitu erythromycin $98,33 \%$, enrofloxacin $94,33 \%$ dan oxytetracyclin $86,67 \%$. Hasil tersebut berbeda sekali dengan hasil uji di laboratorium. Hal tersebut mungkin dapat disebabkan karena kondisi kualitas air kolam relatif lebih baik dan juga didukung tersedianya pakan alami yang memadai. Sedangkan di laboratorium selain dengan sumber air yang berbeda (sumber air tanah) yang biasanya sifatnya tidak stabil ( $\mathrm{pH}$ dan suhu), juga pakan yang tidak ditambah dengan pakan alami, maka semua faktor di atas merupakan tekanan-tekanan (stress factors) bagi kehidupan larva tersebut sehingga mengakibatkan rendahnya laju sintasan.

Hasil perlakuan tersebut tidak menunjukkan adanya perbedaan dengan kontrol $(74,33 \%)$. Keadaan demikian dimungkinkan karena tidak terjadi kasus infeksi bakteri pada kolam tersebut, sehingga kurang dapat dibedakan dengan jelas antara ketahanan ikan yang diperlakukan dengan antibiotik dengan yang tidak diperlakukan. Salah satu cara untuk membedakannya adalah dengan jalan menginfeksi (uji tantang) dengan bakteri patogen, tapi hal ini tidak dilakukan karena tadinya diharapkan adanya infeksi secara alami.

Penggunaan erythromycin dengan cara perendaman ternyata harus dipertimbangkan kembali mengingat antibiotik tersebut relatif sukar larut dalam air, sehingga untuk mendapatkan suatu larutan yang homogen cukup sulit. Sebetulnya untuk mempercepat kelarutannya bisa dengan menggunakan ethanol atau methanol sebanyak $0,5 \mathrm{~mL}$ untuk tiap satu gram erythromycin. Namun demikian setidaknya akan timbul masalah lain yaitu berupa efek dari alkohol atau methanol itu sendiri terhadap ikan.

Penggunaan vaksin aeromonas di kolam tidak menunjukkan hasil yang memuaskan. Hal tersebut di atas karena mekanisme kerja vaksin adalah sangat spesifik terhadap patogen sejenis, 
sedangkan di kolam mungkin terdapat berbagai macam bakteri penyebab penyakit. Jadi kematian ikan uji dapat diakibatkan oleh jenis bakteri lain, bukan diakibatkan oleh bakteri Aeromonas hydrophila.

\section{KESIMPULAN DAN SARAN}

Dari hasil tersebut di atas dapat diambil kesimpulan bahwa iodin $(2,5 \mathrm{mg} / \mathrm{L})$ dan phenol $(1,0 \mathrm{mg} / \mathrm{L})$ dapat digunakan untuk perlakuan telur sebagai usaha peningkatan daya tetasnya. Demikian juga oxytetracyclin dan enrofloxacin dapat digunakan untuk perlakuan larva bagi peningkatan sintasan larva.

\section{DAFTAR PUSTAKA}

Anderson, I.G. 1992. The use of chemotherapeutic agents in finfish and shelfish culture in Australia. In: Diseases in Asian Aquaculture I. M Shariff, R.P. Subashinghe and J.R. Arthur (eds). Fish Health Section, Asian Fisheries Society, Manila, Philippines. 493-504

Baticados, M.C.L. and J.O. Paclibare. 1992. The use of chemotherapeutic agents in aquaculture in the
Philippines. In: Diseases in Asian Aquaculture I. M Shariff, R.P. Subashinghe and J.R. Arthur (eds). Fish Health Section, Asian Fisheries Society, Manila, Philippines. 531-546

Plumb, J.A. 1992. Disease control in aquaculture. In: Diseases in Asian Aquaculture I. M Shariff, R.P. Subashinghe and J.R. Arthur (eds). Fish Health Section, Asian Fisheries Society, Manila, Philippines. 03-17

Sachlan, M. 1975. Parasit, penyakit dan hama burayak ikan. Kumpulan Diktat Menuju Intensifikasi Budidaya Ikan Air Tawar. Training Centre Perikanan Sukabumi. 37 hal.

Supriyadi, H. 1992. Identifikasi dan cara penanggulangan penyakit bakterial pada ikan nila. Pros. Seminar Hasil Pen. Perik. Air Tawar 1991/1992 Cipayung 20-22 Oktober 1992. Hambali Supriyadi et al. (eds). Balai Penelitian Perikanan Air Tawar. Bogor. Pusat Penelitian dan Pengembangan Perikanan. Badan Penelitian dan Pengembangan Pertanian. 59-63.

Wohlfarth, G. W. and G. Hulata. 1983. Applied genetics of tilapia. ICLARM Studies and Review. International Centre for Living Aquatic Resource Management, Manila, Philippines. 26 p. 